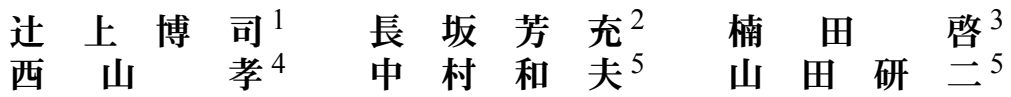

\title{
Investigation into the Decomposition Processing of Methane Hydrate Using Cooling Optical Microscope
}

by Hiroshi TSUJIGAMI ${ }^{\mathrm{a}}$, Yoshimitsu NAGASAKA ${ }^{\mathrm{b}}$, Hiromu KUSUDA ${ }^{\mathrm{b}}$,

Takashi NISHIYAMA $^{\mathrm{b}}$, Kazuo NAKAMURA ${ }^{\mathrm{c}}$ and Kenji YAMADA ${ }^{\mathrm{c}}$

a. Department of Energy Science \& Technology, Kyoto University (Present at Iwatani Co., Ltd.)

b. Department of Energy Science \& Technology, Kyoto University, Sakyo-ku, Kyoto 606-8501, Japan

c. Osaka Gas Co., Ltd.

It has been speculated that there are large oceanic methane hydrate deposits adjacent to Japan, and it is important to elucidate the mechanical and chemical properties of the hydrate to develop commercial technologies for identifications and extracting hydrate concentrations to utilize these resources. The occurrence of methane hydrate is controlled by severe conditions such as high pressure and low temperature and the decomposition processes of synthetic methane were observed microscopically hydrate under the conditions of a wide range of temperatures and atmospheric conditions. The results are summarized as follows:

(1) Microscopic observation of thin sections of synthetic methane hydrate is available using a sample sowed by microtome using a tungsten knife covered with a plastic plate. However, it is very difficult to reduce the hydrate to a thickness of about $0.02 \mathrm{~mm}$, which is the common thickness for rock thin sections. Hydrate and ice are identified under crossed nicols based on the differences in crystal systems.

(2) Occurrence of the common decomposition in methane hydrate processes were observed at temperature increases of between $2{ }^{\circ} \mathrm{C} / \mathrm{min}$ and $10^{\circ} \mathrm{C} / \mathrm{min}$ and in the temperature range of $-100-0{ }^{\circ} \mathrm{C}$. When methane hydrate was maintained at $5^{\circ} \mathrm{C}$ or $10^{\circ} \mathrm{C}$ on the surface of the thin section, it took about 10 or 100 minutes respectively for the hydrate to decompose into methane and ice. When the temperature of methane hydrate was increased at a high rates, a small amount of ice gradually formed until temperature reached $0{ }^{\circ} \mathrm{C}$, and then a large amount of ice was shortly formed near $0{ }^{\circ} \mathrm{C}$. When the rate of temperature increases was low, ice was formed slowly and at an even rate. We speculated that this phenomenon was related to self-preservation. Based on the results of this study, we found that for a long period of time is required to decompose methane hydrate into methane and ice or water.

KEY WORDS : Methane Hydrate, Cooling Microscope, Decomposition Processing

1. 緒言

メタンハイドレートは世界各地に賦存し (佐藤, 1994), 日本周 辺海域においても，大量に存在していることが明らかになってき た (Michael，2000)。すなわち，オホーツク海 (網走沖), 奥尻海嶺 ( 日本海), 千島海溝周辺 (十勝, 日高沖), 西津軽海盆 (日本海), 南海トラフ ( 四国〜東海沖) での存在が示唆されており, 平成 11 〜 12 年に, 南海トラフにおいて基礎試錐も実施されている(石田, 2000)。これら日本周辺海域におけるメタンガス埋蔵量はフリーガ 又領域と合わせると約 9 兆 $\mathrm{m}^{3}$ に達するとされており (Michael, 2000)，これはわが国の年間天然ガス消費量の約 100 倍以上に相当 する膨大な量である。

* 2001 年 4 月 2 日受付 2002 年 2 月 22 日受理

1. 京都大学大学院生 エネルギー科学研究科 (現 岩谷産業(株))

2. 京都大学大学院生 エネルギー科学研究科

3. 普通会員 工博 京都大学助教授 大学院エネルギー科学研究科

4. 普通会員 工博 京都大学教授 大学院エネルギー科学研究科

5. 大阪ガス (株) 開発研究部

[著者連絡先 ] FAX 075-753-5428 (京大・エネルギー科学研究科) E-mail : kusuda@kumst.kyoto-u.ac.jp

キーワード : メタンハイドレート, 冷却顕微鏡, 分解プロセス
しかしながら, メタンハイドレートを資源として活用するには, 探查, 開発法, コストなどに種々の問題を抱えている。そこで, 本研究では, メタンハイドレートを鉱物学的な観点から, 冷却顕 微鏡を用いて, 光学的観察を行い, 分解プロセスの観察を試みた。

\section{2. 供 試 試 料}

メタンハイドレート供試試料は, 人工的に合成されたものであ り, 直径が約 $1.5 \mathrm{~cm}$ の棒状で，外見は氷とよく似ている (Fig.1)。 本研究に用いたメタンハイドレートは次のような工程で, 大阪ガ 又研究開発部で生成された。

まず，水蒸気，メタンを原材料として低温・高圧下 $\left(10{ }^{\circ} \mathrm{C}, 10\right.$ MPa) で一週間攪拌し，ハイドレートを合成する。次に合成装置か ら得られたサンプルを圧力晶析装置によりさらに高圧下 $(160$ $\mathrm{MPa})$ で精製し，余剩水分を極力脱離した。

この合成されたメタンハイドレート試料を，常温常圧下のもと で放置すると, 時間の経過に伴ってメタンガスが放出され $5 \sim 6 \%$ 質量が減少する (Fig.2)。 


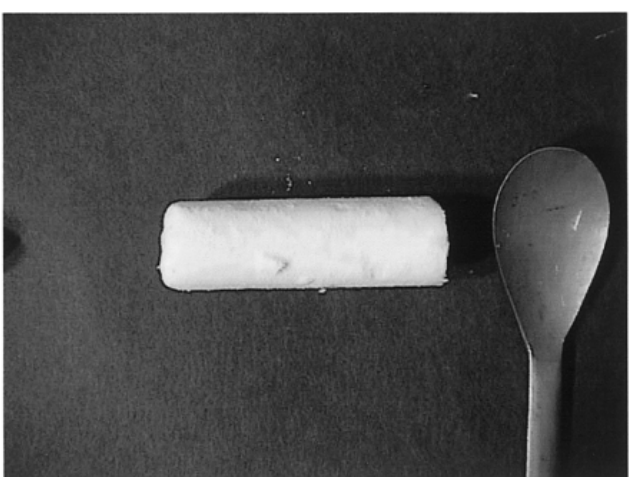

Fig.1 Synthetic methane hydrate.

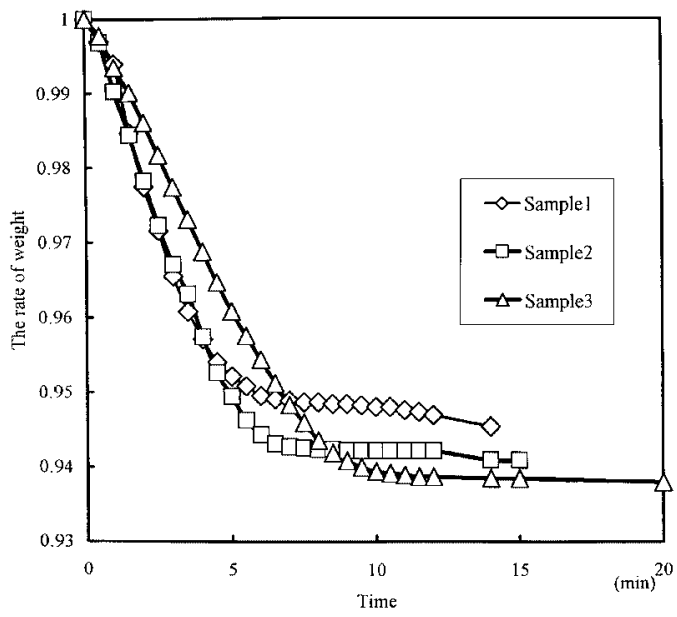

Fig.2 Time progress of weight of methane hydrate.
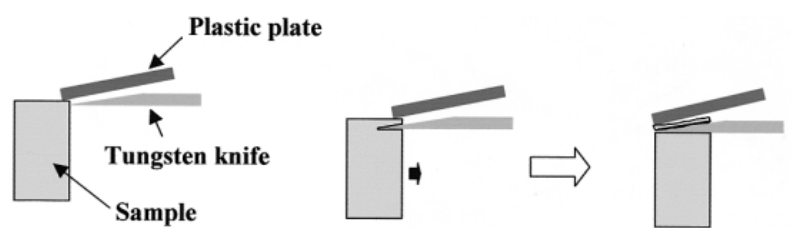

Fig.3 The method to obtain a thin section.

\section{3. 冷却顕微鏡による観察}

\section{$3 \cdot 1$ 観察試料の作製}

通常, 偏光顕微鏡観察では, 試料を約 $20 \mu \mathrm{m}$ の厚さにした薄片 を観察している。したがって, 既存のデータと比較するには, メ タンハイドレートの観察にも，同程度の厚さの薄片を作製するの が望ましい。そこで，人工メタンハイドレートを，冷却切断機 (ミクロトーム) を用いて, $-30^{\circ} \mathrm{C} の$ 室内温度のもとで試料の切断 を行った。ミクロトームは水や生物標本など薄片作製に使われて いるものであるが，メタンハイドレートを切断するとローリング によって蛇腹状になるため平面状の試料が得られず，観察に耐え るような薄片ができない。これまでの研究では，あらかじめテー プを用いて形状を保持してから切断すると, 適切に切断が進むこ とがあるが，経験を要し，非効率的である。そこで，通常使われ ているステンレス製ナイフを，タングステンナイフに替え，アン チロールプラスチック板で試料を押さえながら，ゆっくりと切断 すると，比較的薄く切断できることがわかった（Fig.3）。しかし， この方法でも，波状になるのはさけられず，また $20 \mu \mathrm{m}$ より厚い 薄片となるが，顕微鏡下での観察が可能な程度の試料が得られる (Fig.4)。

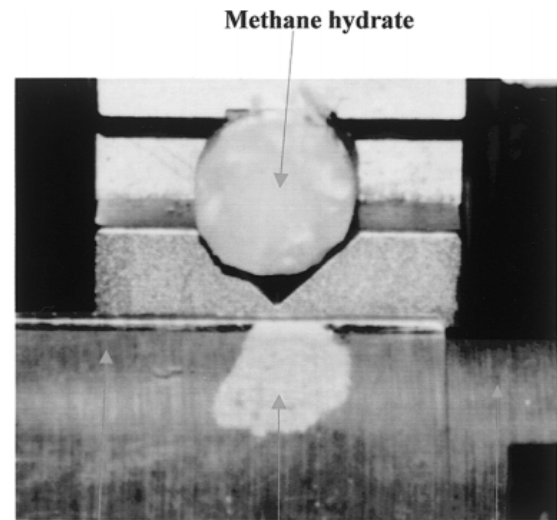

Plastic plate Thin section Tungsten knife

Fig.4 The sample sowed by microtome.

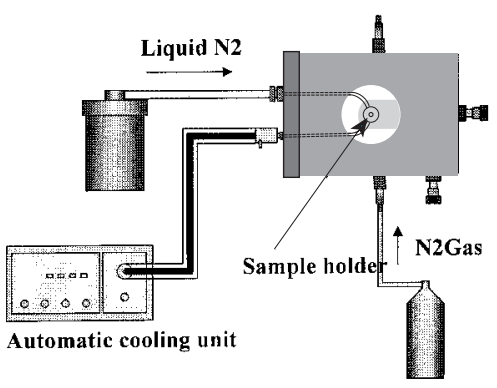

Fig.5 Schematic illustration of cooling system for microscopic observation.

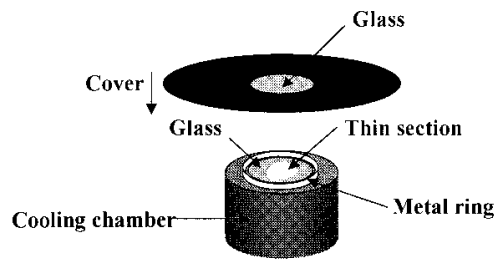

Fig.6 Schematic illustration of sample holder.

\section{$3 \cdot 2$ 冷却顕微鏡による観察}

冷却装置はジャパンハイテック社製 L-500A を，顕微鏡はオリ ンパス社製の BX50-33P( 長作動距離対物レンズ使用 ) を用いた。 概念図は Fig.5 に示寸とおりである。自動冷却ユニットにより循 環させる液体窒素を調節しながら観察セル内部を冷却する。冷却 時に試料に霜が付くので, $\mathrm{N}_{2}$ ドライガスを微量封入することでセ ル内の水蒸気を除去する。また, セル上部空ガラスに $\mathrm{N}_{2}$ ドライ ガスを吹き付けることにより霜の付着を防ぐ。しかし, 温度計測 用熱電対はセル直下にあるため, 試料の上端と下端で温度差が生 じるおそれがある。薄片は極めて薄いものであるため, この温度 差は少ないものと予想されるが，温度差を極力低減するために， 温度調節セル部分に, 試料載置板にのせた薄片をのせ, 薄片の回 りを金属リングで囲んだ (Fig.6)。この装置を使うことにより，温 度を上昇させながら試料の変化を観察することができる。

この冷却装置を顕微鏡に組み込み, パソコンと接続された CCD カメラをとおして観察，撮影を行った。

\section{4. 観察結果および考察}

\section{$4 \cdot 1$ メタンハイドレートと氷の観察}

まず，代表的な水とメタンハイドレートを冷却顕微鏡で観察し た。氷試料は市販されているもので, 観察結果は Fig. $7 \mathrm{~b}$ に示すと 

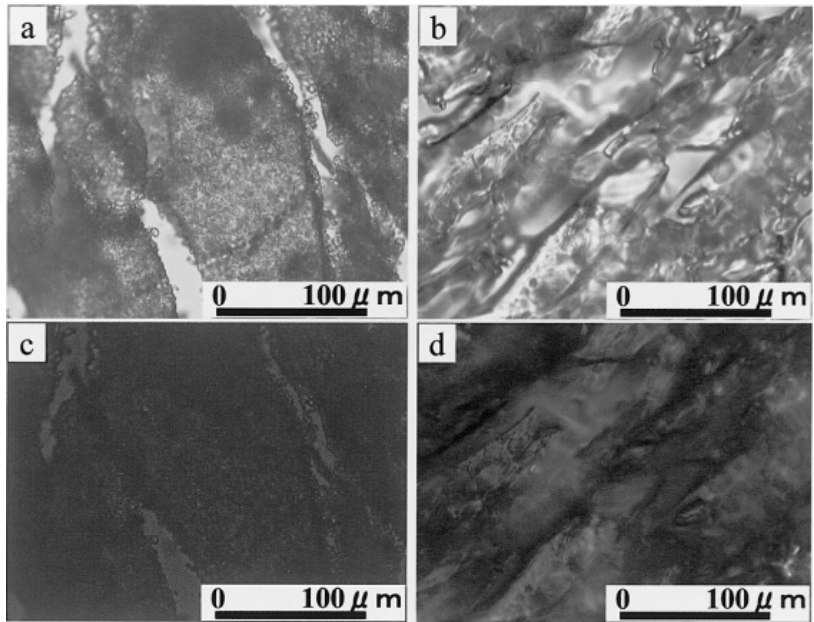

Fig.7 Microphotographs of methane hydrate and ice.

a) methane hydrate, single nicol b) ice, single nicol

c) methane hydrate, crossed nicols d) ice, crossed nicols

おりで多結晶である。氷は六方晶系で，干渉色は灰白色である。 しかし，すでに述べたように，ミクロトームで切断された薄片で は灰色になっており，干渉図表からすると厚さは $60 \mu \mathrm{m}$ 以上と推 察される。

メタンハイドレートの観察結果を Fig.7a に示す。メタンハイド レートは等軸結晶で多結晶であり，クロスニコルでは基本的には 光は透らず暗くなる。このことから, 水とメタンハイドレートと はクロスニコルのもとで識別できる。

\section{$4 \cdot 2$ メタンハイドレートの分解プロセス}

これまでの研究 (Sloan, 1990) によれば，メタンハイドレートの 相平衡図は Fig.8 のように表され，この図はメタンハイドレート が，メタンと水あるいは氷に分解する基本的概念を与えているが， 分解プロセスあるいは分解時間は考慮されていない。しかし，メ タン回収システムの構築や鉱床の成因の考察においても，分解時 間は極めて重要な要素である。そこで，メタンハイドレートの分 解プロセスの概念を把握するために, 大気圧 $(0.1 \mathrm{MPa})$ 下で, メ夕 ンハイドレート分解と氷の形成の違い，一定の速さで温度を上昇 させたとき，および一定温度で保持したときのメタンハイドレー 卜の分解プロセスを観察した。

$4 \cdot 2 \cdot 1$ 水およびメタンハイドレートの昇温による分解の相違

温度調節セル部分の昇温速度を $5{ }^{\circ} \mathrm{C} / \mathrm{min}$ に設定し, $-30 \sim 0$ ${ }^{\circ} \mathrm{C}$ まで昇温したときの水およびメタンハイドレートの観察を 行った。Fig. 9 は, $-30^{\circ} \mathrm{C},-5^{\circ} \mathrm{C}, 0{ }^{\circ} \mathrm{C}$ のきの観察結果を比較し

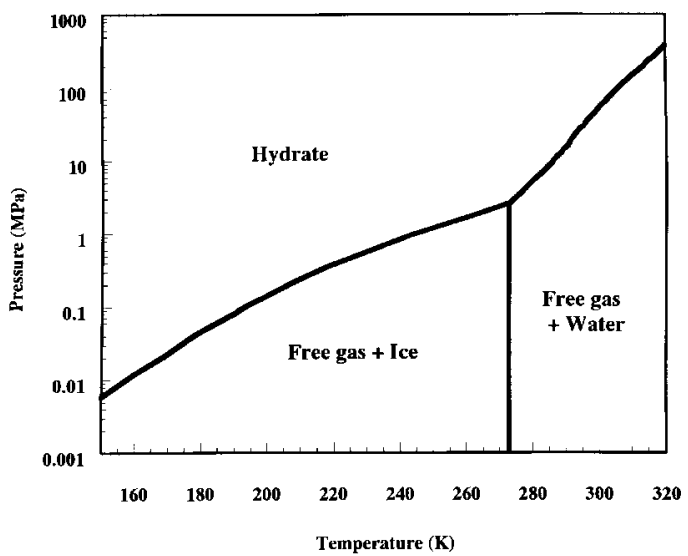

Fig.8 Equilibrium phase diagram of methane hydrate (Sloan, 1990).

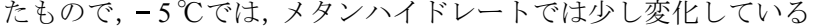

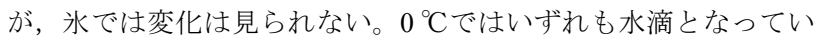
るが, メタンハイドレートではメタンからなると思われる気泡が 観察される。

$4 \cdot 2 \cdot 2$ 昇温速度を変えたときのメタンハイドレートの分解

次に, メタンハイドレートの昇温による変化を詳細に観察し た。温度調節セル部分の昇温速度を $2^{\circ} \mathrm{C} / \mathrm{min}, 10^{\circ} \mathrm{C} / \mathrm{min}$ と変え, $-30^{\circ} \mathrm{C},-20^{\circ} \mathrm{C},-5{ }^{\circ} \mathrm{C}$ ときに観察された像が Fig. 10 である。分 解の進行に伴い，水が成長しているのがわかるが，昇温速度 $2{ }^{\circ} \mathrm{C}$ $/ \min$ ではきれいな水の結晶が見られるのに対して, $10{ }^{\circ} \mathrm{C} / \mathrm{min}$ と 速くなると結晶は小さくなり，シャーベット状になっているもの と思われる。顕微鏡下で識別できる水を画像処理により抽出した のが Fig.11であり，その量を表したのが，Fig.12である。 $-30{ }^{\circ} \mathrm{C}$ から $-5{ }^{\circ} \mathrm{C}$ まで時間をかけて昇温させるほど, 分解により水の量 が増えていることがわかる。

$4 \cdot 2 \cdot 3$ 温度を一定にしたときのメタンハイドレートの分解

相平衡図によると， $0.1 \mathrm{MPa}$ 下では $-80^{\circ} \mathrm{C}$ 以下でないと安定 にならない。そこで温度調節セルの温度を, $-30{ }^{\circ} \mathrm{C},-20{ }^{\circ} \mathrm{C},-15$ ${ }^{\circ} \mathrm{C},-5{ }^{\circ} \mathrm{C}$ の 5 段階とし， 10 分ごとに $\mathrm{CCD}$ カメラで撮影し，分解 状況を調べた。Fig.13に, その結果の一部, $-30^{\circ} \mathrm{C}$ と $-5{ }^{\circ} \mathrm{C}$ のき の変化を示す。時間の経過とともに氷の成長が見られ，顕下で識 別できる水を抽出すると Fig.14のようになる。また氷の成長量を 相対的に表したのが Fig. 15 である。保持温度が $-5{ }^{\circ} \mathrm{C}$ であると, 10 分後以降, 氷の量はほぼ一定になることから, 分解が終了した と考えられる。同様に, $-15^{\circ} \mathrm{C}$ で保持すると約 40 分で, $-20^{\circ} \mathrm{C}$ あ るいは $-30^{\circ} \mathrm{C}$ で保持すると約 100 分で分解が終わっている。

なお，クロスニコルのもとで，すべての水が識別されるわけで はなく, 消光位あるいはそれに近い状態の水は識別できない。そ こで偏光板を 45 度回転させて観察を行った。その結果は Fig.16 に 示すとおりで, 単ニコルで観察される粒子は，いずれかで識別さ れ，分解終了後に残ったものはほとんどが水の粒子と判断される。

\section{$4 \cdot 3$ 気泡の観察結果}

$-20{ }^{\circ} \mathrm{C}$ 付近の挙動を，より詳細に観察した。すなわち，セル内
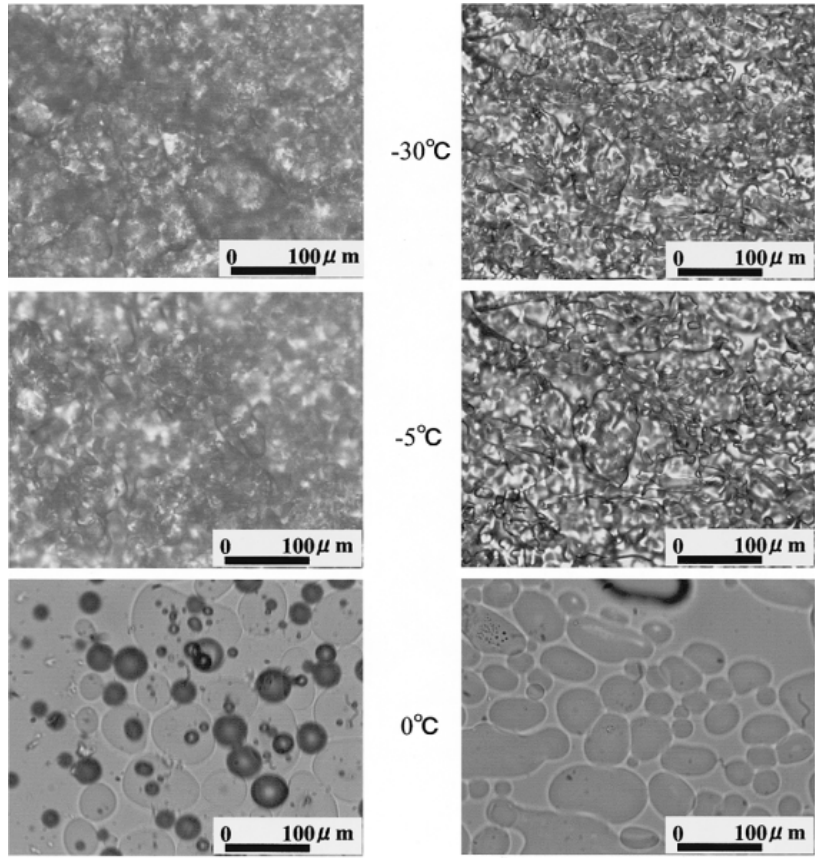

b) ice

a) methane hydrate

Fig.9 Decomposition of methane hydrate and ice. 


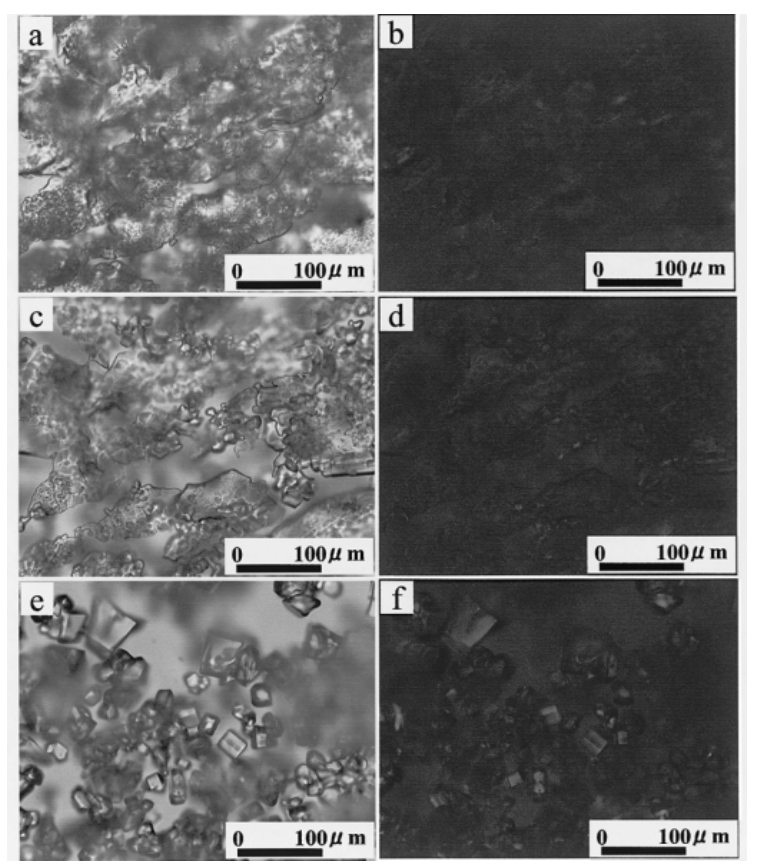

Fig.10-1 Decomposition of methane hydrate as rising temperature (heating speed $2 \mathrm{C} / \mathrm{min}$ )
a) single nicol at $-30^{\circ} \mathrm{C}$
c) single nicol at $-15^{\circ} \mathrm{C}$
b) crossed nicols at $-30^{\circ} \mathrm{C}$
e) single nicol at $-5^{\circ} \mathrm{C}$
f) crossed nicols at

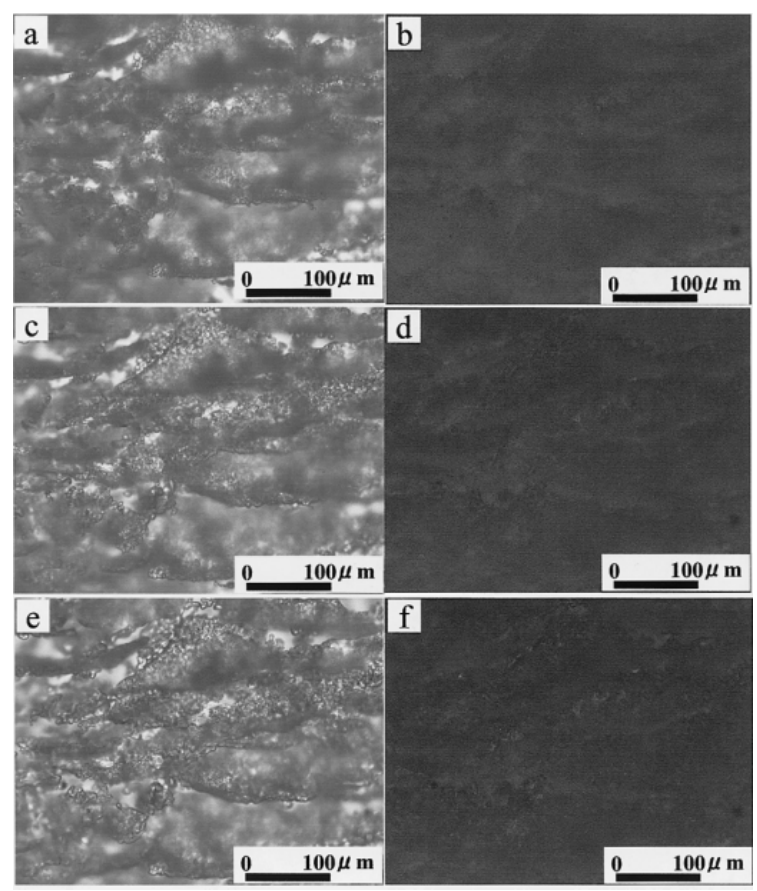

Fig.10-2 Decomposition of methane hydrate as rising temperature (heating speed $10^{\circ} \mathrm{C} / \mathrm{min}$ ).

a) single nicol at $-30^{\circ} \mathrm{C} \quad$ b) crossed nicols at $-30^{\circ} \mathrm{C}$

c) single nicol at $-15^{\circ} \mathrm{C} \quad$ d) crossed nicols at $-15^{\circ} \mathrm{C}$

e) single nicol at $-5^{\circ} \mathrm{C} \quad$ f) crossed nicols at $-5^{\circ} \mathrm{C}$

部には窒素ガスを流入させたまま観察を行った。その結果, -20 ${ }^{\circ} \mathrm{C}$ 付近で分解が起こっているのが確認された。その状態のまま温 度を $-50{ }^{\circ} \mathrm{C}$ まで下げて観察すると, 分解は停止した。もう一度 $-20{ }^{\circ} \mathrm{C}$ に温度を上げると，再び分解が始まるのが観察された。ま た，顕著に分解が起こっている箇所で，粒子の境界部分からメ夕 ンと思われる気泡が確認された Fig.17)。
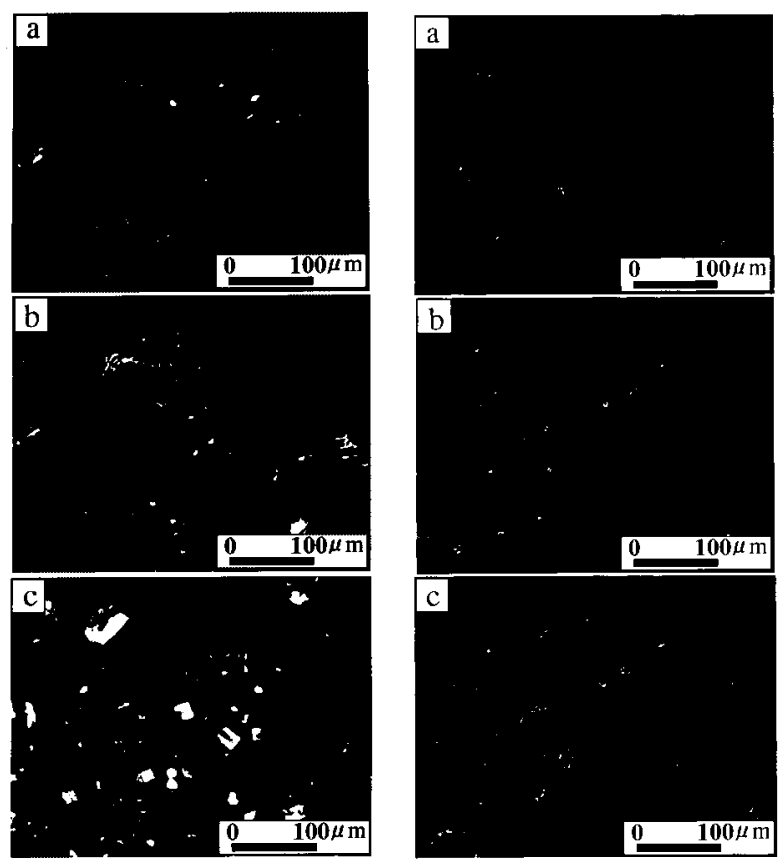

heating speed $2^{\circ} \mathrm{C} / \mathrm{min}$
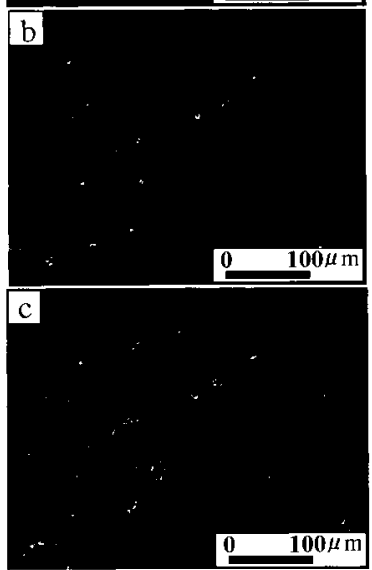

heating speed $10^{\circ} \mathrm{C} / \mathrm{min}$

Fig.11 Image of ice extracted by image processing. a) $-30^{\circ} \mathrm{C} \quad$ b) $-15^{\circ} \mathrm{C} \quad$ c) $-5^{\circ} \mathrm{C}$

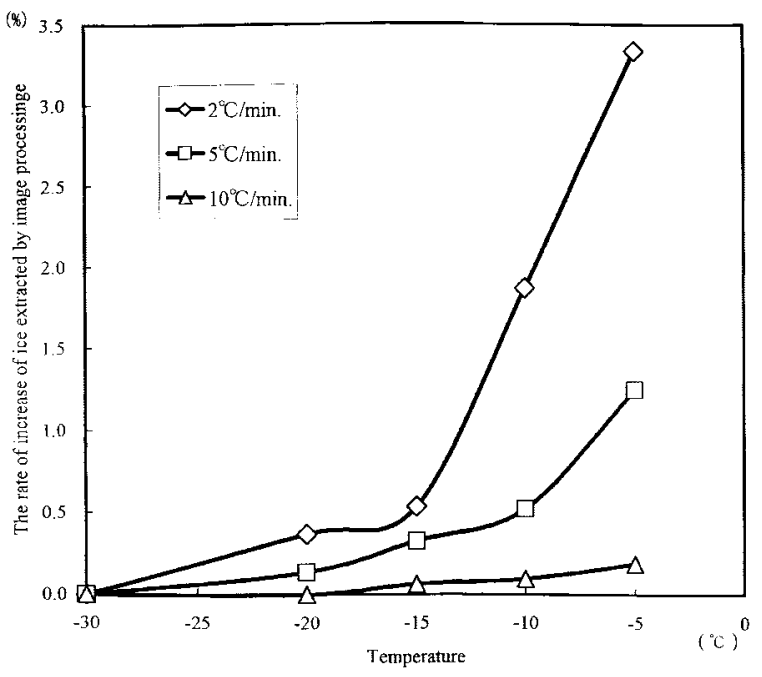

Fig.12 Progress of decomposition phenomena of methane hydrate under various heating speeds.

\section{$4 \cdot 4$ 考察}

メタンハイドレートが不安定な温度, 圧力領域で, フリーガス と永に分解していく過程は明らかでない。分解に伴って形成され る水が分解を抑制することも報告されている (Yakushev, 2000 ; 海 老沼ら，2000)。本研究においては，メタンハイドレートの分解プ 口セスを定性的に把握することができたが，氷と共存する $0{ }^{\circ} \mathrm{C}$ 以 下でも理論的な相平衡曲線どおりに急激に分解が進まないことが わかった。また, 分解の進行に伴って氷部分が増加し, 分解後は 数多くの水の結晶が残ることが明らかになった。

さらに，メタンガスと思われる気泡が，粒子の境界部分から発 生するのも観察された。この時の設定温度は $-20{ }^{\circ} \mathrm{C}$ あ゙あが，乾 燥窒素を流すために試料表面はわずかに温度が高くなっているた めに, 表面部分のメタンハイドレートが分解し, 残存する水の中 にメタンガスの気泡が生じたものと考えられる。 


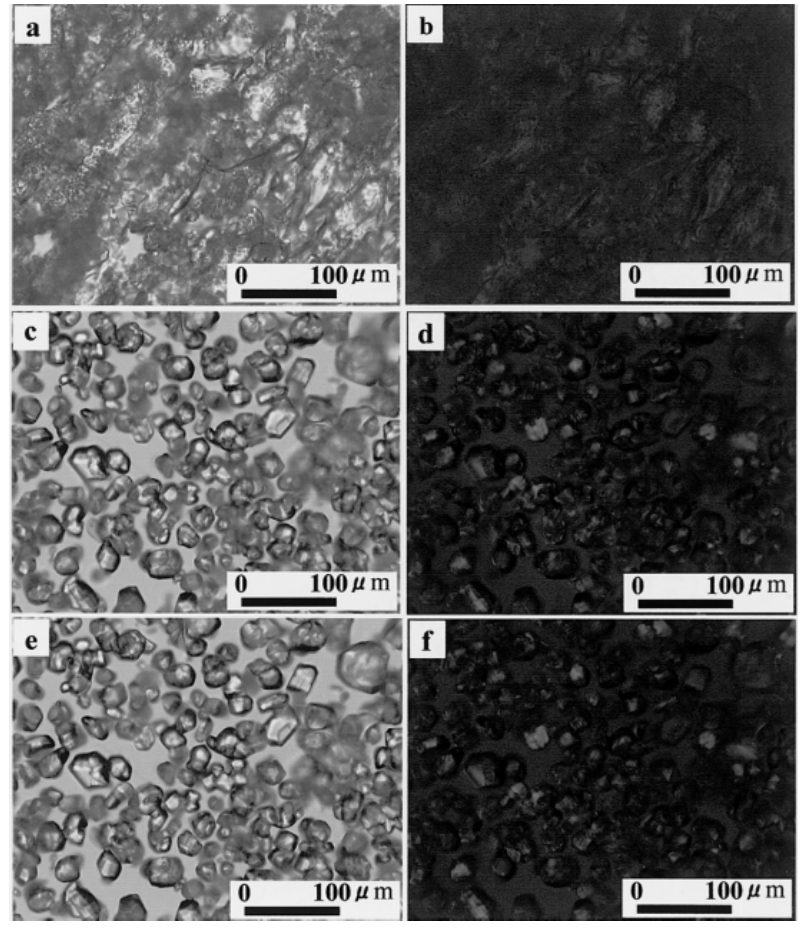

Fig.13-1 Progress of decomposition phenomena of methane hydrate at $-30^{\circ} \mathrm{C}$

a) 0min. single nicol

b) 0min. crossed nicols

c) after $100 \mathrm{~min}$. single nicol

d) after 100min. crossed nicols

e) after $120 \mathrm{~min}$. single nicol

after $120 \mathrm{~min}$. crossed nicols

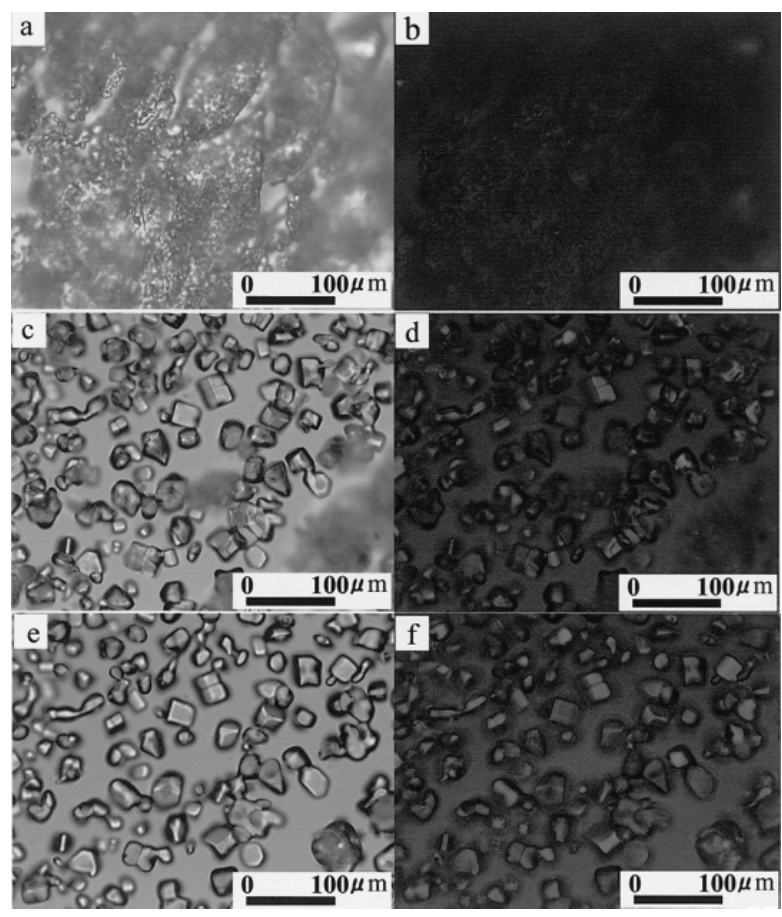

Fig.13-2 Progress of decomposition phenomena of methane hydrate at $-5^{\circ} \mathrm{C}$.
a) 0min. single nicol
b) 0min. crossed nicols
c) after $10 \mathrm{~min}$. single nicol
d) after $10 \mathrm{~min}$. crossed nicols
e) after $20 \mathrm{~min}$. single nicol
f) after $20 \mathrm{~min}$. crossed nicols

メタンハイドレートは，水分子が作る籠状構造がある程度崩れ て，中のメタン分子が飛び出すことにより分解すると考えられてい る (灘, 1999)。飛び出したメタン分子が集合してメタンガスとなり, メタンハイドレート粒子の境界部分から発生すると考えられる。

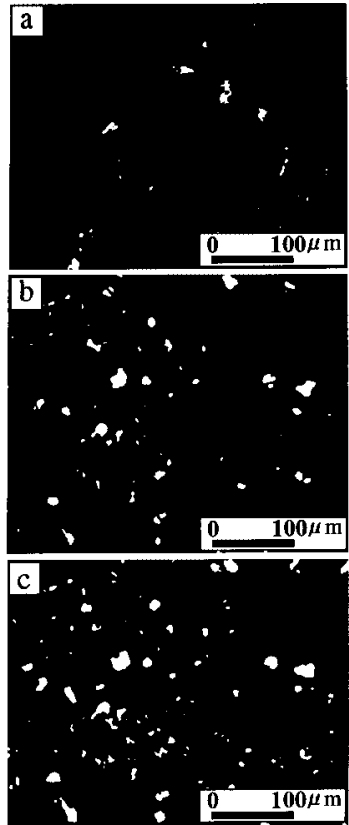

$-30^{\circ} \mathrm{C}$

a) $0 \mathrm{~min} \quad$ b) after $100 \mathrm{~min}$

c) after $120 \mathrm{~min}$

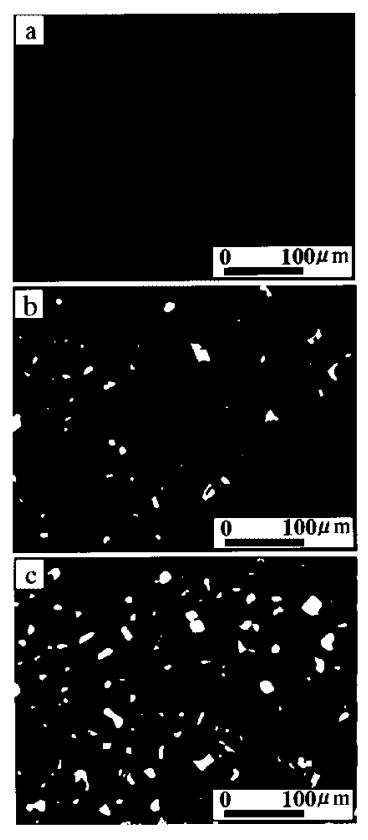

$-5^{\circ} \mathrm{C}$

a) $0 \mathrm{~min} \quad$ b) after $10 \mathrm{~min}$

c) after $20 \mathrm{~min}$
Fig.14 Time variation of ice extracted by image processing.

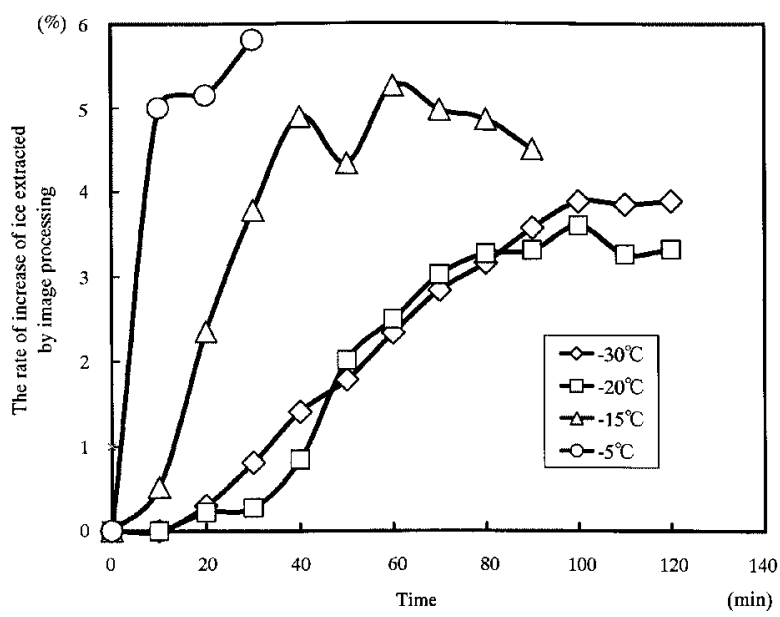

Fig.15 Time variation of the rate of ice extracted by image processing.

\section{5. 結言}

メタンハイドレートの開発方法の手がかりとするために，冷却 顕微鏡を用いて人工メタンハイドレートの分解プロセスを観察し た。その結果，以下のことが明らかになった。

(1) 低温下で安定である人工メタンハイドレートの薄片を作 製するのは困難であるが, タングステンナイフとローリング防止 具を使い，切断速度をコントロールすることにより，顕微鏡下で の観察が可能な試料が得られる。

（2）昇温速度を速くすると水の成長はそれほど見られず， 0 度 付近で急激に分解する。一方, 昇温速度を遅くすると分解の進行 に伴って氷の結晶が成長していくのが観察される。また, 温度調 節セル部分の温度を $-5{ }^{\circ} \mathrm{C}$ 固定した場合, 約 10 分で分解が終了 するが, $-30{ }^{\circ} \mathrm{C}$ で固定した場合は約 100 分かかることがわかり, 分 解にはかなりの時間がかかる。これはメタンハイドレートの開発 においては極めて重要なことである。 


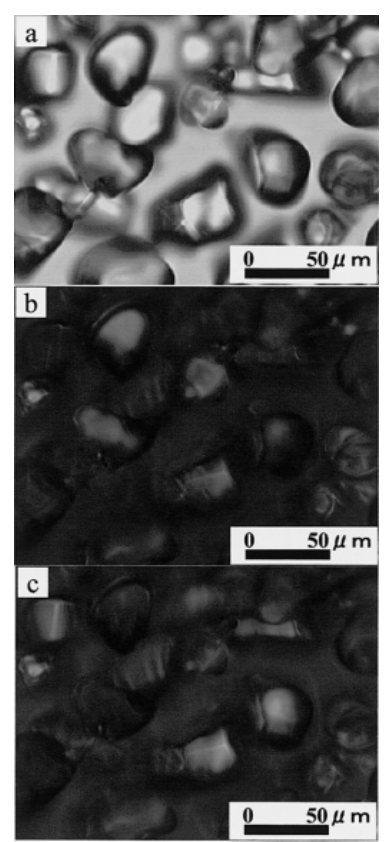

Fig.16 Microphotograph of ice after decomposition of methane hydrate.

a) single nicol b) crossed nicols c) crossed nicols ( $45^{\circ}$ rotation)

（3） 0 度以下の不安定領域では分解の進行に伴って, 水の成長 が見られるが，この水の作用により分解が遅くなるものと思われ る。氷の膜により分解速度が抑制されるという自己保存性に関す る報告もあり，これとよく一致している部分も観察されるが，昇 温速度などにより分解プロセスが大きく異なることも推察される ので，さらに詳細な検討が必要である。
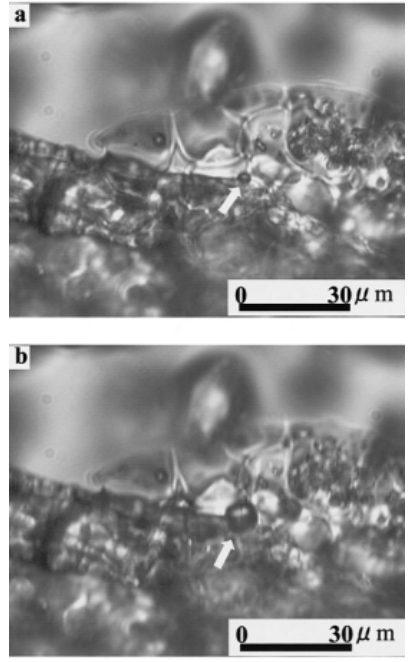

Fig.17 Evolution of methane gas bubble. a) $0 \mathrm{sec}$ b) after $15 \mathrm{sec}$

\section{引用 文 献}

海老沼孝郎・伊達信次・内田 努・成田英夫 (2000) : ガス八イドレートの生成・解離 に関与寸る制御因子の効果確認と定量化一-(1)ガスハイドレートの生成速度に関 する研究一, ガスハイドレート資源化技術先導研究開発フォーラム講演要旨集, p. $102-106$

石田 ${ }^{\text {p耳 }}$ (2000) : 基礎試錐「南海トラフ」の掘削成果について, 第 22 回海洋工学パ ネル, p. $12-21 \mathrm{p}$

Michael, D. Max (Ed.)(2000) : Natural Gas Hydrate, 415p., Kluwer Academic Publishers 灘 浩樹 (1999) : 分子動力学法によるガス八イドレート生成・分解機構の解明, 資源 環境技術総合研究所第 16 回研究講演会資料, p. 9-16

佐藤幹生 (1994): メタンハイドレートの自然界での分布, 月刊地球, 16-9, p. 533-538 Sloan, E. D. (1990) : Clathrate Hydrates of Nnatural Gases, 641p., Mercel Dekker, Inc Yakushev, V. S. (2000) : A Review of Research on Self-preservation of Gas Hydrates, Abstract of Forum on Feasibility Studies on Gas Hydrate for Develpent of Energy Resources, p. 112-117 